\title{
Fasting Blood Glucose Levels and Hematological Values in Normal and Streptozotocin-Induced Diabetic Rats of Mimosa pudica L. Extracts
}

\author{
Ampa Konsue ${ }^{1}$, Chayan Picheansoonthon ${ }^{2,3}$, Chusri Talubmook ${ }^{4}$
}

\section{Ampa Konsue ${ }^{1}$, Chayan Picheansoonthon ${ }^{2,3}$, Chusri Talubmook ${ }^{4}$ \\ ${ }^{1}$ Candidate, Faculty of Medicine, Mahasarakham University, Maha Sarakham, 44000, THAILAND. ${ }^{2}$ Alternative Medicine College Chandrakasem Rajabhat University, Chatuchak, Bangkok 10900, THAILAND. ${ }^{3}$ The Academy of science, The Royal Institute Sanam Suea Pa Khet Dusti Bangkok 10300, THAILAND. ${ }^{4}$ Department of Biology, Faculty of Sciences, Mahasarakham University, Maha Sarakham 44150, THAILAND.}

\section{Correspondence}

Ampa Konsue, Department of Health Sciences, Faculty of Medicine, Maha sarakham University, Maha sarakham, 44000 THAILAND

Phone no: +66 43712992;

Facsimile numbers +66 43712991

E-mail: ampa_ice@hotmail.com

\section{History}

- Submission Date: 18-01-17;

- Review completed: 06-02-17;

- Accepted Date: 07-03-17

DOI : 10.5530/pj.2017.3.54

Article Available online

http://www.phcogj.com/v9/i3

\section{Copyright}

(c) 2017 Phcog.Net. This is an openaccess article distributed under the terms of the Creative Commons Attribution 4.0 International license.

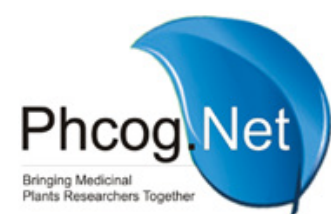

\begin{abstract}
Context M. pudica is a common plant found in moist waste ground, lawns, open plantations and weedy thickets. Aims The fasting blood glucose levels (FBG) and hematological values of $M$. pudica aqueous(MPA) and hydro-ethanolic (MPHE) extract were evaluated in normal and streptozotocin (STZ)-induced diabetic rats. Materials and Methods MPA and MPHE 125, 250 and $500 \mathrm{mg} / \mathrm{kg}$ body weight (b.w.) were administered orally and daily to the rats for 8 weeks. The FBG were determined weekly. Red blood cells (RBC), hemoglobin (Hb), hematocrit $(\mathrm{Hct})$, platelet, mean corpuscular volume (MCV), mean corpuscular hemoglobin $(\mathrm{MCH})$, mean corpuscular hemoglobin concentration $(\mathrm{MCHC})$, white blood cells $(\mathrm{WBC})$, lymphocytes, monocytes, neutrophils and eosinophil were evaluated. Results: MPA and MPHE had no effect on blood glucose levels in normal rats. All doses of all extracts showed significantly $(p<0.05)$ decreasing FBG in diabetic rats. Especially MPA at the dose of $250 \mathrm{mg} / \mathrm{kg}$ b.w. showed more potent significantly $(p<0.05)$ decreasing blood glucose levels than anti-diabetic drug glibenclamide at the end of experiment. All extracts had no effect on RBC, Hb, Hct, platelet, $\mathrm{MCH}, \mathrm{MCHC}$, lymphocytes, monocytes neutrophils and eosinophils. Surprisingly, the extracts were decreased WBC and MCV in diabetic rats. In addition, all of the extracts did not produce the alteration of blood cells structure in all rats. Conclusion: This study indicated that the extracts were hypoglycemic effect and improve hematological values in diabetes which confirms the traditional use of the plant.
\end{abstract}

Key words: Mimosa pudica, Blood glucose level, Hematological values, Red blood cell, White blood cell.

\section{INTRODUCTION}

M. pudica is belonging to family Fabaceae that recommended for preventing and treating various diseases arising from corrupted blood and bile, bilious fever, piles, jaundice, leprosy, ulcer and small pox, amoebic dysentery, bleeding piles, bronchitis, sexual impotency, migraine, insomnia and diabetes. ${ }^{1-4}$ Its pharmacological activities such as wound healing, ${ }^{5,6}$ antimicrobial, ${ }^{7,8}$ analgesic, anti-inflammatory, ${ }^{9}$ anticonvulsant, ${ }^{10}$ antidiarrhea, ${ }^{11,12}$ anti- fertilization, ${ }^{13}$ anti-malaria, ${ }^{14}$ antioxidant, ${ }^{4,8,15}$ hepatoprotective, ${ }^{15,16}$ anti-helmintic, ${ }^{17}$ hypolipidemic, ${ }^{3,18}$ diuretic property, ${ }^{19}$ anti-hyperglycemic, ${ }^{4,20} \alpha$-Glucosidase inhibitory activity ${ }^{21}$ and hyperglycema. ${ }^{22}$ have been reported. Although this plant was widely used for treatment of diabetes. ${ }^{4}$ However, any side effect on diabetic treatment has not yet been demonstrated. Therefore, the purposes of this study were designed to determine the blood glucose levels and hematological values both in normal and STZinduced diabetic rats administering orally with whole plant from $M$. pudica extract.

\section{MATERIALS AND METHODS}

\section{Plant Material}

The plants were collected from Kalasin Province, Northeastern of Thailand. The specimen was identified by the Plant Varieties Protection Division, Depart- ment of Agriculture, Ministry of Agriculture and Cooperatives, Thailand. The voucher specimen is deposited at the Faculty of Medicine, Mahasarakham University, Thailand (code: MSU.Med-MP0001/ $\mathrm{AK})$. The fresh whole plants were dried at $50^{\circ} \mathrm{C}$ for $48 \mathrm{hr}$ in an hot air oven then powdered.

\section{Preparation of MPA and MPHE}

The MPA was prepared by boiling the plant powder in distilled water for $15 \mathrm{~min}(1: 10 \mathrm{w} / \mathrm{v})$. The boiling process was repeated twice. The MPHE were prepared by macerating the plant powder in $50 \%$ ethanol for 7 days $(1: 5 \mathrm{w} / \mathrm{v})$. The residue powder was excluded by using the filter papers. The filtrate was evaporated using rotary evaporator (Heidolph Laborota 4000, Germany) and freeze-dried to obtain dark brown extract. The extracts were kept in the fridge at $-20^{\circ} \mathrm{C}$ until be used. Percent yield of MPA was $9.75 \%$ and MPHE was $7.29 \%$ dry powder.

\section{Animals}

Male albino Wistar rats weighing 150-200 g purchasing from the National Laboratory Animal Centre, Mahidol University, Thailand were used in this study. They were acclimatized in an air conditioned room at $25 \pm 2^{\circ} \mathrm{C}, 12$-h light/12-h dark cycle and relative humidity $50-55 \%$, and given 
a standard chow and watered ad libitum for 7 days prior to the commencing experiment. The rats were maintained in accordance with the guidelines of the Committee Care and Use of Laboratory Animal Resource, National Research Council Thailand, and performed in accordance with the advice of the Institutional Animal Care and Use Committee, Mahasarakham University of Thailand (License, No. 0003/2014).

\section{Induction of diabetic rats}

The animals were injected intraperitoneally with a single dose of $65 \mathrm{mg} / \mathrm{kg}$ b.w. STZ (Sigma Chemicals, St. Louis, MO) dissolved freshly in cold $20 \mathrm{mM}$ citrate buffer adjust to $\mathrm{pH} 4.5 .^{23}$ After injection, they were provided with $2 \%$ sucrose solution for $48 \mathrm{hr}$ to alleviate the discomfort after initiating the hypoglycemic phase. Three days after injection, the rats were examined for FBG to confirm their diabetic stage. The rats with FBG higher than $126 \mathrm{mg} / \mathrm{dL}$ were used in the experiments. ${ }^{24}$

\section{Experimental designs}

The animals were divided into the following sixteen experimental groups with eight animals in each: group I normal control rats treated orally with $0.5 \%$ Tween 80 ; groups II normal rats treated orally with glibenclamide $0.5 \mathrm{mg} / \mathrm{kg}$ b.w.; group III-V normal rats administrated orally with MPA at the doses of 125, 250 and $500 \mathrm{mg} / \mathrm{kg}$ b.w.; group VI normal rats administrated orally with MPHE at the doses of 125, 250 and $500 \mathrm{mg} / \mathrm{kg}$ b.w.; group IX diabetic control rats treated orally with $0.5 \%$ Tween 80 ; group $\mathrm{X}$ diabetic rats treated orally with glibenclamide $0.5 \mathrm{mg} / \mathrm{kg}$ b.w.; group XI-XIII diabetic rats administrated orally with MPA at the doses of 125, 250 and $500 \mathrm{mg} / \mathrm{kg}$ b.w.; group XIV-XVI diabetic rats administrated orally with MPHE at the doses of 125, 250 and $500 \mathrm{mg} / \mathrm{kg}$ b.w. MPA, MPHE and glibenclamide were suspended in $0.5 \%$ Tween 80 and administered orally once a day for 8 weeks using an orogastric tube. The volume of administration was $1 \mathrm{~mL}$ for each animal. After eight weeks of treatments, the rats were fasted overnight then sacrificed by cervical dislocation technique. The blood samples were drawn from the rat heart for determination of hematological values and blood cell structure.

\section{Effect of MPA and MPHE on FBG}

The normal and STZ-induced diabetic rats were fasted overnight before collecting of blood samples. They were taken from the tail vein of the rats. FBG was measured weekly for 8 weeks with Glucometer (Accu-chek Performa, Roche, Germany).

\section{Effect of MPA and MPHE on hematological values}

After 8 weeks of administration, the rats were fasted overnight and then sacrificed by cervical dislocation technique. The blood samples were collected and put into tubes containing $10 \%$ of ethylene diamine tetracetic acid (EDTA) and were used immediately for determination of hematological values including white blood cell count (WBC), red blood cell count (RBC), hemoglobin concentration ( $\mathrm{Hb})$, hematocrit (Hct), mean corpuscular volume $(\mathrm{MCV})$, mean corpuscular hemoglobin $(\mathrm{MCH})$, mean corpuscular hemoglobin concentration $(\mathrm{MCHC})$, platelet (Plt) and differential white blood cell count including lymphocytes, momocytes, neutrophils and eosinophils by using an automatic blood analyzer (Swelab Alfa, Biozen, Sweden).

\section{Effect of MPA and MPHE on blood cell structure}

The blood was smeared then fixed in 95\% ethanol for 5 min and stained with Wright-Geimsa. Structure of blood cells were examined and photographed under a Light Microscope. ${ }^{21}$

\section{Statistical analysis}

All data were expressed as mean \pm standard error of mean (SEM). Statistical analysis was carried out using F-test (One-Way ANOVA) followed by Scheffe's test. The criterion for statistical significance was at a $p$-value less than 0.05 .

\section{RESULTS}

\section{Effect of MPA and MPHE on blood glucose levels}

Table 1 showed effect of MPA and MPHE on the FBG in normal and STZ-induced diabetic rats. The FBG in normal control, normal rats with glibenclamide, MPA and MPHE were not effect. FBG with glibenclamide, MPA and MPHE were significantly $(p<0.05)$ decreasing in diabetic rats. MPA at the dose of $250 \mathrm{mg} / \mathrm{kg}$ b.w. showed significantly $(p<0.05)$ decreasing FBG more potent than MPA $500 \mathrm{mg} / \mathrm{kg}$ b.w and MPHE $125 \mathrm{mg} / \mathrm{kg}$ b.w. All the extracts were decreased FBG slightly better than glibenclamide at the week 5 .

\section{Effect of MPA and MPHE on hematological values}

Table 2 showed the effect of MPA and MPHE on hematological values in normal and STZ-induced diabetic rats. $\mathrm{RBC}, \mathrm{Hb}, \mathrm{Hct}$, platelet, $\mathrm{MCH}$ and $\mathrm{MCHC}$ in normal and diabetic rats were not different. Surprisingly, the treated diabetic rats showed decreasing of WBC and MCV. Interestingly, MPA at the doses of $250 \mathrm{mg} / \mathrm{kg}$ b.w. was significantly $(p<0.05)$ increasing $\mathrm{WBC}$ count in diabetic rats more than glibenclamide.

\section{Effect of MPA and MPHE on differential WBC}

Table 3 showed the effect of MPA and MPHE on differential WBC in normal and STZ-induced diabetic rats. All the doses of MPA and MPHE were not different on lymphocytes, monocytes, neutrophils and eosinophil values both in normal and diabetic rats.

\section{Effect of MPA and MPHE on blood cell structure}

Light micrographs showed the RBC structure, differential WBC structure including lymphocytes, monocytes, neutrophils and eosinophils. The $\mathrm{RBC}$ has unique structure. Their flexible disc shape helps increase the surface area to volume ratio of these extremely small cells. Mature RBC does not contain a nucleus, and a biconcave disc. It is round ball that is squeezed from two opposite ends to appear, widest at the sides and narrowest in the middle. RBC structure of all experimental groups were not different. White blood cells are different in shape and size. They contain nuclei and can be divided into granulocytes (lymphocytes, monocytes, neutrophils and eosinophils). The granules in these WBC are apparent when stained. Lymphocytes these cells are spherical in shape with large nuclei and very little cytoplasm. Monocytes These cells are the largest of the WBC. Neutrophils these cells have a single nucleus that appears to have multiple lobes. They are the most abundant granulocyte. Eosinophils the nucleus in these cells is double lobed and often appears U-shaped. Basophils they are the least numerous of the white blood cells. They have a multi-lobed nucleus, agranulocytes there are two types of agranulocytes also known as nongranular leukocytes: lymphocytes and monocytes. These WBC appear to have no obvious granules. Agranulocytes typically have a large nucleus due to the lack of noticeable cytoplasmic granules. They have a large, single nucleus that can have various shapes. The nucleus often appears to be kidney-shaped. All types of WBC structure of all experimental groups were not different (Figure 1).

\section{DISCUSSION}

The present study was designed to investigate the FBG and hematological values of different $M$. pudica extracts to prove its traditional use. In addition, it was also tested for its effect on the hematological values and blood cell structure in the normal and STZ-induced diabetic Rats. The present 


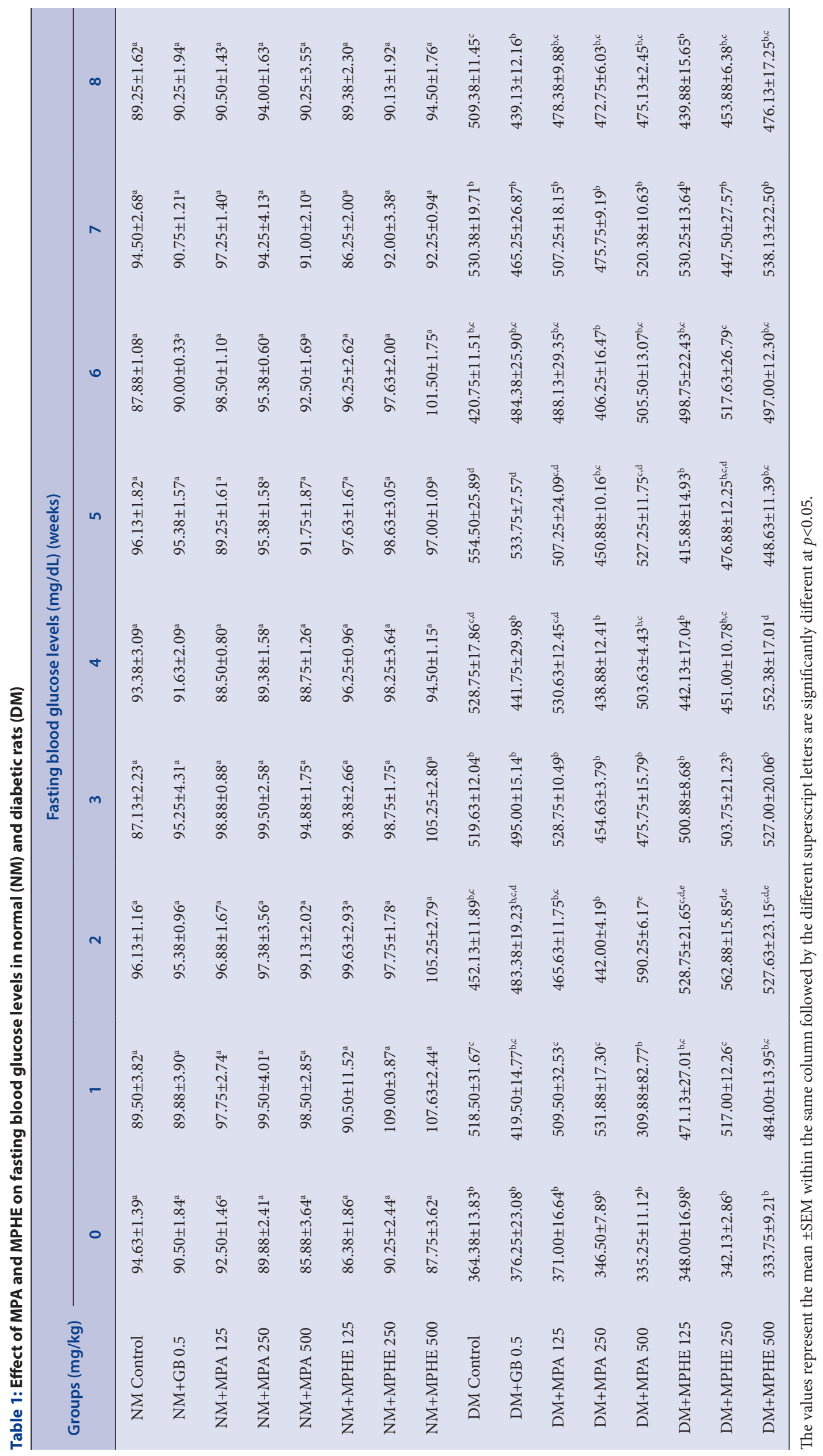


Table 2: Effect of MPA and MPHE on hematological values included red blood cells (RBC), hemoglobin (Hb), hematocrit (Hct), white blood cells (WBC), platelet, mean corpuscular volume (MCV), mean corpuscular hemoglobin (MCH), and mean corpuscular hemoglobin concentration (MCHC) in normal (NM) and diabetic rats (DM)

\begin{tabular}{|c|c|c|c|c|c|c|c|c|}
\hline \multirow[b]{2}{*}{ Groups (mg/kg) } & \multicolumn{8}{|c|}{ Hematological values } \\
\hline & $\begin{array}{c}\text { RBC } \\
\left(\times 10^{6} \text { cells/ }\right. \\
\left.\mathrm{mm}^{3}\right)\end{array}$ & $\begin{array}{c}\mathrm{Hb} \\
(\mathrm{g} / \mathrm{dL})\end{array}$ & $\begin{array}{l}\text { Hct } \\
(\%)\end{array}$ & $\begin{array}{c}\text { WBC } \\
\left(\times 10^{3} \text { cells } / \mu \mathrm{L}\right)\end{array}$ & $\begin{array}{c}\text { Platelet } \\
\left(\times 10^{5} / \mathrm{mm}^{3}\right)\end{array}$ & $\begin{array}{c}\text { MCV } \\
(\mathrm{fL})\end{array}$ & $\begin{array}{r}\mathrm{MCH} \\
(\mathrm{pg})\end{array}$ & $\begin{array}{l}\text { MCHC } \\
\text { (g/dL) }\end{array}$ \\
\hline NM Control & $9.28 \pm 0.08^{\mathrm{a}, \mathrm{b}}$ & $16.96 \pm 0.20^{\mathrm{a}}$ & $52.84 \pm 0.66^{\mathrm{a}, \mathrm{b}}$ & $6.20 \pm 0.21^{\mathrm{f}, \mathrm{g}}$ & $756.75 \pm 6.66^{\mathrm{a}, \mathrm{b}}$ & $56.46 \pm 0.37^{\text {d,e }}$ & $18.13 \pm 0.11^{\mathrm{b}}$ & $32.04 \pm 0.02^{\mathrm{a}, \mathrm{b}, \mathrm{c}}$ \\
\hline $\mathrm{NM}+\mathrm{GB} 0.5$ & $10.04 \pm 0.45^{\mathrm{a}, \mathrm{b}}$ & $16.75 \pm 0.39^{\mathrm{a}}$ & $52.95 \pm 1.69^{\mathrm{a}, \mathrm{b}}$ & $7.10 \pm 0.26^{\mathrm{g}}$ & $733.00 \pm 29.67^{\mathrm{a}, \mathrm{b}}$ & $54.20 \pm 0.38^{\mathrm{a}, \mathrm{b}, \mathrm{c}, \mathrm{d}}$ & $17.20 \pm 0.15^{\mathrm{a}, \mathrm{b}}$ & $31.73 \pm 0.29^{\mathrm{a}, \mathrm{b}, \mathrm{c}}$ \\
\hline NM+MPA 125 & $9.52 \pm 0.07^{\mathrm{a}, \mathrm{b}}$ & $16.43 \pm 0.14^{\mathrm{a}}$ & $51.57 \pm 0.16^{\mathrm{a}, \mathrm{b}}$ & $5.00 \pm 0.19^{\mathrm{b}, c, \mathrm{~d}, \mathrm{e}, \mathrm{f}}$ & $861.50 \pm 22.14^{\mathrm{b}, \mathrm{c}}$ & $53.43 \pm 0.15^{\mathrm{a}}$ & $17.03 \pm 0.16^{\mathrm{a}, \mathrm{b}}$ & $31.83 \pm 0.20^{\mathrm{a}, \mathrm{b}, \mathrm{c}}$ \\
\hline $\mathrm{NM}+\mathrm{MPA} 250$ & $9.27 \pm 0.27^{\mathrm{a}, \mathrm{b}}$ & $15.99 \pm 0.56^{\mathrm{a}}$ & $51.03 \pm 1.85^{\mathrm{a}, \mathrm{b}}$ & $6.34 \pm 0.36^{\mathrm{f}, \mathrm{g}}$ & $989.50 \pm 20.61^{\mathrm{c}}$ & $54.95 \pm 0.28^{\mathrm{a}, \mathrm{b}, \mathrm{d}, \mathrm{e} e}$ & $17.23 \pm 0.05^{\mathrm{a}, \mathrm{b}}$ & $31.61 \pm 0.07^{\mathrm{a}, \mathrm{b}, \mathrm{c}}$ \\
\hline NM+MPA 500 & $9.35 \pm 0.07^{\mathrm{a}, \mathrm{b}}$ & $16.18 \pm 0.17^{\mathrm{a}}$ & $50.44 \pm 0.46^{\mathrm{a}, \mathrm{b}}$ & $5.85 \pm 0.20^{\mathrm{d}, e, \mathrm{f}, \mathrm{g}}$ & $822.13 \pm 17.83^{\mathrm{a}, \mathrm{b}, \mathrm{c}}$ & $53.90 \pm 0.16^{\mathrm{a}}$ & $17.26 \pm 0.11^{\mathrm{a}, \mathrm{b}}$ & $32.04 \pm 0.11^{\mathrm{a}, \mathrm{b}, \mathrm{c}}$ \\
\hline NM+MPHE 125 & $9.17 \pm 0.10^{\mathrm{a}, \mathrm{b}}$ & $16.18 \pm 0.33^{\mathrm{a}}$ & $50.18 \pm 0.57^{a}$ & $5.93 \pm 0.32^{\mathrm{e}, \mathrm{fg}}$ & $763.75 \pm 25.04^{\mathrm{a}, \mathrm{b}, \mathrm{c}}$ & $54.70 \pm 0.34^{\mathrm{a}, \mathrm{b}, \mathrm{c}, \mathrm{d}}$ & $17.60 \pm 0.26^{\mathrm{a}, \mathrm{b}}$ & $32.18 \pm 0.34^{\mathrm{b}, \mathrm{c}}$ \\
\hline NM+MPHE 250 & $9.51 \pm 0.15^{\mathrm{a}, \mathrm{b}}$ & $16.63 \pm 0.25^{\mathrm{a}}$ & $52.10 \pm 0.70^{\mathrm{a}, \mathrm{b}}$ & $6.13 \pm 0.32^{\mathrm{fg} g}$ & $812.75 \pm 26.13^{\mathrm{a}, \mathrm{b}, \mathrm{c}}$ & $54.83 \pm 0.43^{\mathrm{a}, \mathrm{b}, \mathrm{c}, \mathrm{d}}$ & $17.50 \pm 0.23^{\mathrm{a}, \mathrm{b}}$ & $31.95 \pm 0.27^{\mathrm{a}, \mathrm{b}, \mathrm{c}}$ \\
\hline NM+MPHE 500 & $9.89 \pm 0.34^{\mathrm{a}, \mathrm{b}}$ & $16.88 \pm 0.36^{\mathrm{a}}$ & $52.08 \pm 1.17^{\mathrm{a}, \mathrm{b}}$ & $5.83 \pm 0.20^{\text {c,d,ef, } \mathrm{gg}}$ & $805.00 \pm 28.31^{\mathrm{a}, \mathrm{b}, \mathrm{c}}$ & $54.08 \pm 0.21^{\mathrm{a}, \mathrm{b}}$ & $17.53 \pm 0.07^{\mathrm{a}, \mathrm{b}}$ & $32.43 \pm 0.26^{c}$ \\
\hline DM Control & $9.91 \pm 0.04^{\mathrm{a}, \mathrm{b}}$ & $17.13 \pm 0.27^{\mathrm{a}}$ & $54.40 \pm 0.33^{\mathrm{a}, \mathrm{b}}$ & $5.88 \pm 0.25^{\mathrm{e}, \mathrm{fg}}$ & $682.00 \pm 27.22^{\mathrm{a}, \mathrm{b}}$ & $56.40 \pm 0.35^{c, d, e}$ & $17.20 \pm 0.42^{\mathrm{a}, \mathrm{b}}$ & $31.88 \pm 0.61^{\mathrm{a}, \mathrm{b}, \mathrm{c}}$ \\
\hline $\mathrm{DM}+\mathrm{GB} 0.5$ & $9.09 \pm 0.15^{\mathrm{a}, \mathrm{b}}$ & $15.44 \pm 0.15^{\mathrm{a}}$ & $50.19 \pm 0.50^{\mathrm{a}}$ & $2.77 \pm 0.26^{\mathrm{a}}$ & $621.25 \pm 62.69^{\mathrm{a}}$ & $54.74 \pm 0.40^{\mathrm{a}, \mathrm{b}, \mathrm{c}, \mathrm{d}}$ & $16.89 \pm 0.10^{\mathrm{a}}$ & $30.58 \pm 0.30^{\mathrm{a}, \mathrm{b}, \mathrm{c}}$ \\
\hline DM+MPA 125 & $8.85 \pm 0.23^{\mathrm{a}}$ & $16.69 \pm 0.10^{\mathrm{a}}$ & $54.30 \pm 0.47^{\mathrm{a}, \mathrm{b}}$ & $3.92 \pm 0.17^{\mathrm{a}, \mathrm{b}}$ & $700.88 \pm 21.54^{\mathrm{a}, \mathrm{b}}$ & $55.50 \pm 0.07^{\mathrm{a}, \mathrm{b}, \mathrm{c}, \mathrm{d}, \mathrm{e}}$ & $17.06 \pm 0.01^{\mathrm{a}, \mathrm{b}}$ & $30.74 \pm 0.09^{\mathrm{a}, \mathrm{b}, \mathrm{c}}$ \\
\hline DM+MPA 250 & $10.57 \pm 0.18^{\mathrm{b}}$ & $17.40 \pm 0.24^{\mathrm{a}}$ & $57.05 \pm 0.75^{\mathrm{b}}$ & $5.29 \pm 0.10^{b, c, d, e, f}$ & $763.25 \pm 14.48^{\mathrm{a}, \mathrm{b}, \mathrm{c}}$ & $55.26 \pm 0.15^{\mathrm{a}, \mathrm{b}, \mathrm{c}, \mathrm{d}, \mathrm{e}}$ & $16.85 \pm 0.05^{\mathrm{a}}$ & $30.54 \pm 0.02^{\mathrm{a}, \mathrm{b}}$ \\
\hline DM+MPA 500 & $9.22 \pm 0.10^{\mathrm{a}, \mathrm{b}}$ & $16.19 \pm 0.22^{\mathrm{a}}$ & $52.54 \pm 0.93^{\mathrm{a}, \mathrm{b}}$ & $4.20 \pm 0.15^{\mathrm{a}, \mathrm{b}, \mathrm{c}, \mathrm{d}}$ & $793.13 \pm 46.00^{\mathrm{a}, \mathrm{b}, \mathrm{c}}$ & $54.51 \pm 0.19^{\mathrm{a}, \mathrm{b}, \mathrm{c}, \mathrm{d}}$ & $16.81 \pm 0.15^{\mathrm{a}}$ & $30.81 \pm 0.17^{\mathrm{a}, \mathrm{b}, \mathrm{c}}$ \\
\hline DM+MPHE 125 & $10.31 \pm 0.13^{\mathrm{a}, \mathrm{b}}$ & $17.24 \pm 0.09^{\mathrm{a}}$ & $55.66 \pm 0.09^{\mathrm{a}, \mathrm{b}}$ & $4.43 \pm 0.19^{\mathrm{a}, \mathrm{b}, \mathrm{c}, \mathrm{d}, \mathrm{e}}$ & $720.75 \pm 0.49^{\mathrm{a}, \mathrm{b}}$ & $55.19 \pm 0.50^{\text {a,b,c,d,e }}$ & $16.92 \pm 0.07^{\mathrm{a}, \mathrm{b}}$ & $30.65 \pm 0.12^{\mathrm{a}, \mathrm{b}, \mathrm{c}}$ \\
\hline DM+MPHE 250 & $9.80 \pm 0.18^{\mathrm{a}, \mathrm{b}}$ & $16.95 \pm 0.26^{\mathrm{a}}$ & $55.95 \pm 0.78^{\mathrm{a}, \mathrm{b}}$ & $4.18 \pm 0.22^{\mathrm{a}, \mathrm{b}, \mathrm{c}}$ & $709.00 \pm 54.46^{\mathrm{a}, \mathrm{b}}$ & $57.18 \pm 0.20^{\mathrm{e}}$ & $17.33 \pm 0.03^{\mathrm{a}, \mathrm{b}}$ & $30.30 \pm 0.05^{\mathrm{a}}$ \\
\hline DM+MPHE 500 & $9.10 \pm 0.28^{\mathrm{a}, \mathrm{b}}$ & $17.01 \pm 0.21^{\mathrm{a}}$ & $56.15 \pm 1.34^{\mathrm{a}, \mathrm{b}}$ & $3.73 \pm 0.10^{\mathrm{a}, \mathrm{b}}$ & $681.13 \pm 32.40^{\mathrm{a}, \mathrm{b}}$ & $56.16 \pm 0.35^{\mathrm{b}, \mathrm{c}, \mathrm{d}, \mathrm{e}}$ & $17.04 \pm 0.08^{\mathrm{a}, \mathrm{b}}$ & $30.34 \pm 0.35^{\mathrm{a}, \mathrm{b}}$ \\
\hline
\end{tabular}

The values represent the mean \pm SEM within the same column followed by the different superscript letters are significantly different at $p<0.05$.

Table 3: Effect of MPA and MPHE on differential white blood cells, lymphocytes, monocytes, neutrophils and eosinophil in normal (NM) and diabetic rats (DM)

\begin{tabular}{|c|c|c|c|c|}
\hline \multirow{2}{*}{$\begin{array}{l}\text { Groups } \\
\text { (mg/kg) }\end{array}$} & \multicolumn{4}{|c|}{ Differential white blood cells (\%) } \\
\hline & Lymphocytes & Monocytes & Neutrophils & Eosinophil \\
\hline NM Control & $70.76 \pm 2.55^{\mathrm{a}}$ & $1.04 \pm 0.21^{\mathrm{a}}$ & $27.11 \pm 2.45^{\mathrm{a}}$ & $1.09 \pm 0.12^{\mathrm{a}}$ \\
\hline $\mathrm{NM}+$ glibenclamide 0.5 & $86.69 \pm 1.34^{\mathrm{a}}$ & $0.83 \pm 0.18^{\mathrm{a}}$ & $11.71 \pm 1.18^{\mathrm{a}}$ & $0.78 \pm 0.30^{\mathrm{a}}$ \\
\hline NM+MPA 125 & $85.00 \pm 0.53^{\mathrm{a}}$ & $0.27 \pm 0.03^{\mathrm{a}}$ & $13.63 \pm 0.68^{\mathrm{a}}$ & $1.10 \pm 0.15^{\mathrm{a}}$ \\
\hline $\mathrm{NM}+\mathrm{MPA} 250$ & $84.24 \pm 1.00^{\mathrm{a}}$ & $0.75 \pm 0.05^{\mathrm{a}}$ & $14.29 \pm 0.83^{\mathrm{a}}$ & $0.73 \pm 0.18^{\mathrm{a}}$ \\
\hline NM+MPA 500 & $85.18 \pm 1.18^{\mathrm{a}}$ & $1.27 \pm 0.32^{\mathrm{a}}$ & $13.18 \pm 0.90^{\mathrm{a}}$ & $0.38 \pm 0.03^{\mathrm{a}}$ \\
\hline NM+MPHE 125 & $87.78 \pm 0.13^{\mathrm{a}}$ & $0.20 \pm 0.04^{\mathrm{a}}$ & $10.95 \pm 0.29^{\mathrm{a}}$ & $1.08 \pm 0.19^{\mathrm{a}}$ \\
\hline NM+MPHE 250 & $88.95 \pm 0.45^{\mathrm{a}}$ & $0.18 \pm 0.04^{\mathrm{a}}$ & $9.30 \pm 0.36^{\mathrm{a}}$ & $1.58 \pm 0.18^{\mathrm{a}}$ \\
\hline NM+MPHE 500 & $88.90 \pm 0.46^{\mathrm{a}}$ & $0.35 \pm 0.06^{\mathrm{a}}$ & $9.13 \pm 0.28^{\mathrm{a}}$ & $1.63 \pm 0.24^{\mathrm{a}}$ \\
\hline DM Control & $82.23 \pm 0.40^{\mathrm{a}}$ & $1.88 \pm 0.28^{\mathrm{a}}$ & $15.13 \pm 0.28^{\mathrm{a}}$ & $0.78 \pm 0.11^{\mathrm{a}}$ \\
\hline $\mathrm{DM}+$ glibenclamide 0.5 & $89.61 \pm 0.28^{\mathrm{a}}$ & $1.39 \pm 0.13^{\mathrm{a}}$ & $8.26 \pm 0.63^{\mathrm{a}}$ & $0.74 \pm 0.22^{\mathrm{a}}$ \\
\hline DM+MPA 125 & $78.13 \pm 0.30^{\mathrm{a}}$ & $0.75 \pm 0.19^{\mathrm{a}}$ & $19.50 \pm 0.46^{\mathrm{a}}$ & $0.36 \pm 0.08^{\mathrm{a}}$ \\
\hline $\mathrm{DM}+\mathrm{MPA} 250$ & $74.34 \pm 1.01^{\mathrm{a}}$ & $1.11 \pm 0.27^{\mathrm{a}}$ & $23.88 \pm 1.22^{\mathrm{a}}$ & $0.68 \pm 0.06^{\mathrm{a}}$ \\
\hline $\mathrm{DM}+\mathrm{MPA} 500$ & $80.63 \pm 0.98^{\mathrm{a}}$ & $2.50 \pm 0.10^{\mathrm{a}}$ & $16.13 \pm 0.92^{\mathrm{a}}$ & $0.73 \pm 0.08^{\mathrm{a}}$ \\
\hline DM+MPHE 125 & $80.31 \pm 2.06^{\mathrm{a}}$ & $0.60 \pm 0.07^{\mathrm{a}}$ & $18.69 \pm 1.92^{\mathrm{a}}$ & $0.40 \pm 0.07^{\mathrm{a}}$ \\
\hline DM+MPHE 250 & $83.53 \pm 0.79^{a}$ & $4.10 \pm 1.05^{\mathrm{a}}$ & $11.90 \pm 1.57^{\mathrm{a}}$ & $0.48 \pm 0.12^{\mathrm{a}}$ \\
\hline DM+MPHE 500 & $74.63 \pm 2.53^{\mathrm{a}}$ & $1.07 \pm 0.25^{\mathrm{a}}$ & $23.50 \pm 2.66^{\mathrm{a}}$ & $0.80 \pm 0.21^{\mathrm{a}}$ \\
\hline
\end{tabular}

The values represent the mean \pm SEM within the same column followed by the different superscript letters are significantly different at $p<0.05$. 


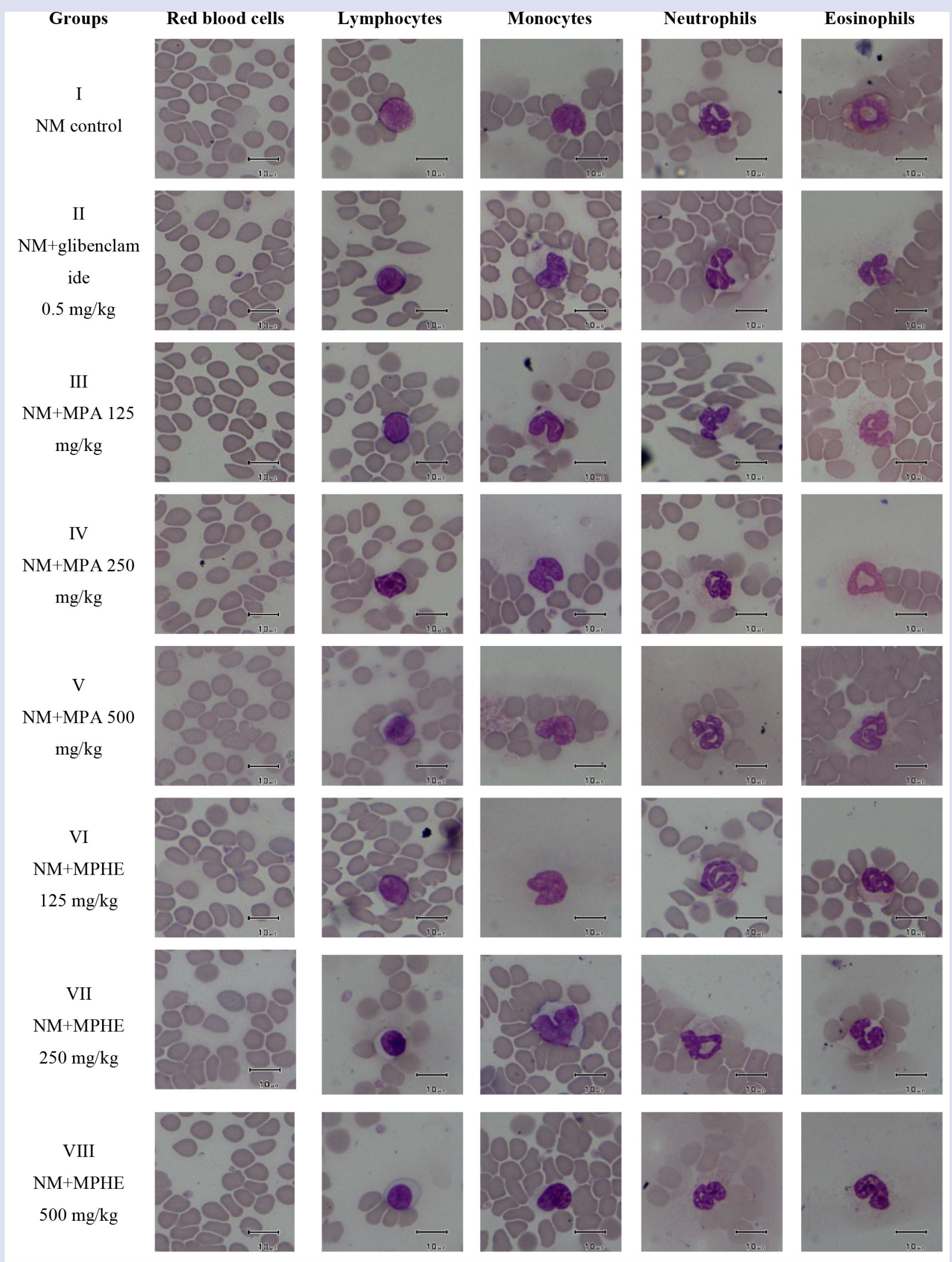

continued... 


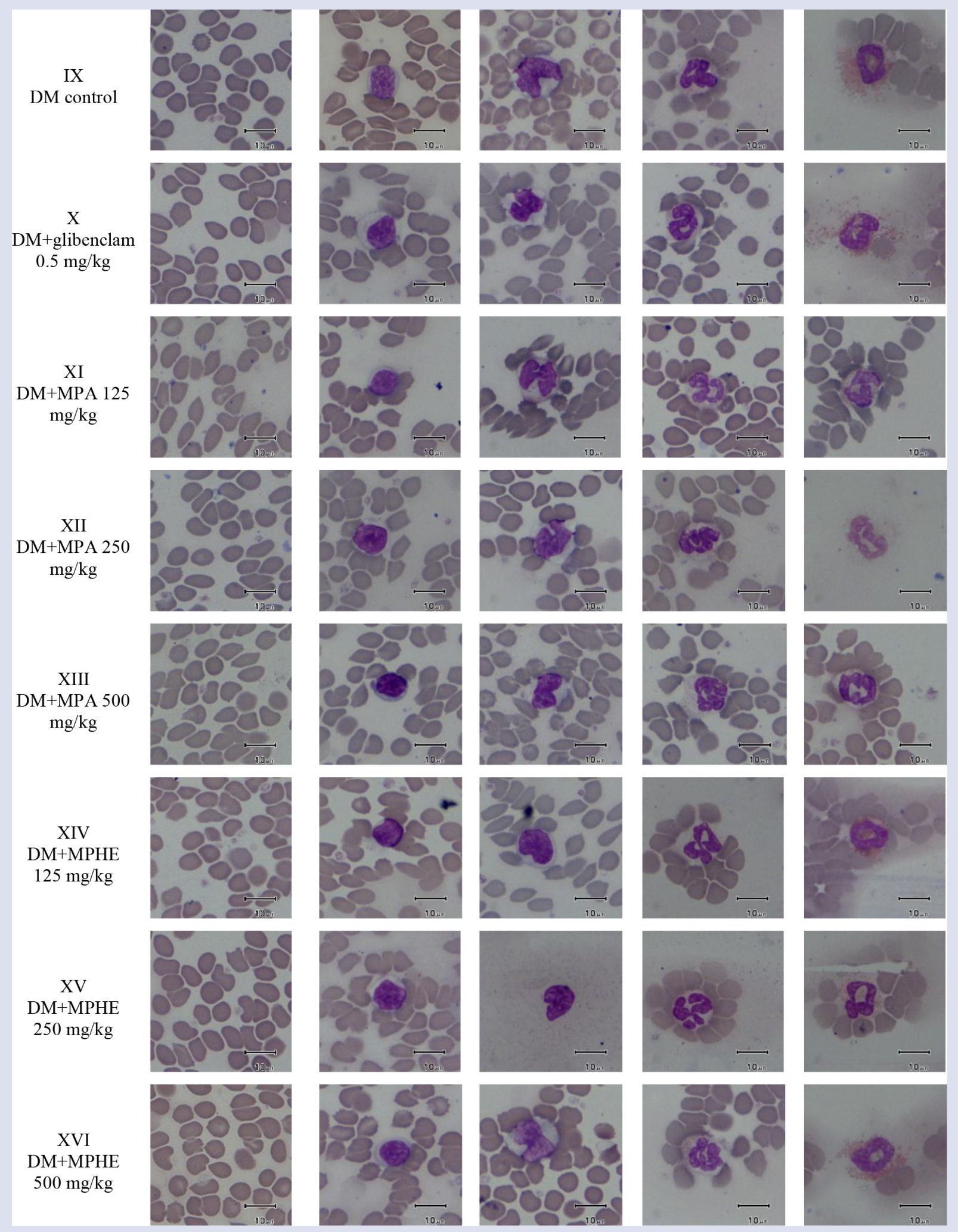

Figure 1: Wright-Giemsa staining shows the structure of RBC and WBC from normal control rats (I), normal rats treated with glibenclamide $0.5 \mathrm{mg} / \mathrm{kg}$ b.w. (II), normal rats treated with MPA and MPHE at the doses 125,250 and $500 \mathrm{mg} / \mathrm{kg}$ b.w. (III, IV, V, VI, VII, VIII) diabetic control rats (IX), diabetic rats treated with Glibenclamide $0.5 \mathrm{mg} / \mathrm{kg}$ b.w. (X), diabetic rats treated with MPA and MPHE at the doses of 125, 250 and $500 \mathrm{mg} / \mathrm{kg}$ b.w. (XI, XII, XII, XIV, XV, XVI). 
study, STZ $65 \mathrm{mg} / \mathrm{kg}$ b.w. was selected in order to partially destroy the $\beta$-cell of pancreas and consequently the rats became permanently diabetes. ${ }^{25,26}$ The results showed that MPA had a hypoglycemic effect by decreasing FBG but not in a dose dependent manner. ${ }^{27,28}$ The hypoglycemic effect of MPA and MPHE were not different in normal rats. MPA at the dose of $250 \mathrm{mg} / \mathrm{kg}$ b.w. showed more potent effect than glibenclamide $\left(0.5 \mathrm{mg} / \mathrm{kg}\right.$ b.w.) which is probably the optimum dose. ${ }^{4,20} \mathrm{WBC}$ count was reduced in diabetic treated rats. However, granulocytes of the diabetic rats were close to those of normal control rats. The observed leukopenia may be due to the suppressing effect of the immune system by STZ thereby reducing the number of WBC. A reduction in the number of WBC could also be as a result of diabetes induced stress which breaks down the rat defensive mechanism. ${ }^{29}$ Diabetic rats treated with all doses of the extracts showed improvement in WBC count. Mechanism of experiment could probably be due to the fact that the extract contains some constituents that stimulate and/or promote the production of $\mathrm{WBC}$ and hence offer some form of protection to the rat immune system. ${ }^{30}$

Effects of the extracts from $M$. pudica in this study on hematological values and blood cell structure in diabetic rats was not difference from normal rats because MPA and MPHE have varied therapeutic potential which all have their own therapeutic impact ${ }^{4,20,21}$ observing in this study may also be due to the ameliorative effects of the extracts on the oxidative damage associated with diabetes. ${ }^{29-30}$

Most of the plants with antidiabetic properties have been found to contain metabolites such as glycosides, alkaloids, and flavonoids., ${ }^{4,22}$ The plant composition such as steroids, tannins, flavonoids and phenolic compounds have been reported. ${ }^{11,15}$ The plant constituent such as kaempferol and stigmasterol are known to improve insulin stimulating glucose uptake. ${ }^{31-33}$ Although the major components that possess antidiabetic activity in the $M$. pudica extract were not precisely identified in this study. However the phytochemical analysis of the whole plant extract revealed the presence of alkaloids, flavonoids, tannins, saponins and glycosides that could be stimulated insulin secretion as well. ${ }^{32}$ The extracts in the present study possess hypoglycemic activity may be due to these chemical substances responsible for this activity. Further study, the underlying mechanism of hypoglycemic effect of the extract from M. pudica has to be clarified.

\section{CONCLUSION}

The results from this study in particularly $M$. pudica aqueous extract support the traditional use of the plant for diabetic treatment and health promoting agent for prevention of diabetes. The aqueous extract also prevents diabetes and improves the hematological values.

\section{ACKNOWLEDGEMENT}

The research was partially supported by the Development Research Division, Mahasarakham University, Faculty of Medicine, Mahasarakham University and National Research Council of Thailand (NRCT).

\section{CONFLICT OF INTEREST}

None

\section{ABBREVIATIONS USED}

FBG: Fasting blood glucose levels; STZ: Streptozotocin; MPA: Aqueous extract; MPHE: Hydro-ethanolic extract; RBC: Red blood cells; Hb: Hemoglobin; Hct: Hematocrit; MCV: Mean corpuscular volume; $\mathbf{M C H}$ : Mean corpuscular hemoglobin; MCHC: Mean corpuscular hemoglobin concentration; WBC: White blood cells; NM: Normal rats; DM: Diabetic rats.

\section{REFERENCES}

1. Rajkumar MH, Sringeswara AN, Rajanna MD. Ex-situ conservation of medicinal plants at university of agricultural sciences, Bangalore, Karnataka. Rec Res Sci Tech. 2013;3(4):21-7.

2. Joseph B, George J, Mohan J. Pharmacology and traditional uses of Mimosa pudica. IJPSDR. 2013;5(2):41-4.

3. Sowmya A, Ananthi T. Hypolipidemic activity of Mimosa pudica Linn on butter induced hyperlipidemia in rats. AJPS. 2011;1(4):123-6.

4. Manosroi J, Moses ZZ, Manosroi W, Manosroi A. Hypoglycemic activity of Thai medicinal plants selected from the Thai/Lanna medicinal recipe database MANOSROI II, J Ethnopharmacol. 2011;138(1):92-8. https://doi.org/10.1016/j. jep.2011.08.049; PMid:21925259.

5. Kannan S, Aravinth S, Sam E, Kumar J, Saminathan K, Suthakaran R, et al. Wound healing activity of Mimosa pudica Linn formulation. Int J Chem Tech Res. 2009;11(4):1554-8.

6. Kokane DD, More RY, Kale KB, Nehete MN. Evaluation of wound healing activity of root of Mimosa pudica. J Ethnopharmacol. 2009;124(2):311-5. https://doi. org/10.1016/j.jep.2009.04.038; PMid:19397984.

7. Kaur P, Kumar N, Shivananda TN, Kaur G. Phytochemical screening and antimicrobial activity of the plant extracts of Mimosa pudica L. against selected microbes. JMPR. 2011;5(12):5356-9

8. Chowdhury SA, Islam J, Rahaman M Md, Rahman M Md, Rumzhum N, Sultana $R$, et al. Cytotoxicity, antimicrobial and antioxidant studies of the different plant parts of Mimosa pudica. SJPS. 2008;1(1\&2):80-4.

9. Chandrashekar D K, Manthale DM. Invention of analgesic and anti-Inflammatory activity of ethanolic extract of Mimosa pudica Linn leaves. EJBPS 2012;1(1):36-8.

10. Ngo Bum E, Dawack DL, Schmutz M, Rakotonirina A, Rakotonirina SV, Portet C, et al. Anticonvulsant activity of Mimosa pudica decoction. Fitoterapia. 2004;75 (3-4):309-14. https://doi.org/10.1016/j.fitote.2004.01.012; PMid:15158987.

11. Khalid MS, Shah JK, Suresh D K, Singh RK, Reddy NIV, Kumar S. Evaluation of anti-diarrhoeal potential of ethanolic extract of Mimosa pudica leaves. IJGP 2011;5(1):75-8. https://doi.org/10.4103/0973-8258.82096.

12. Chaddha VR, Kushwah AS, Shrivastava $V$, An importance of herbal drugs as antidiarrhoeal: areview. IMPACT: IJRANSS. 2013;1(7):25-8.

13. Ganguly M, Devi N, Mahanta R, Borthakur MK. Effect of Mimosa pudica root extract on vaginal estrous and serum hormones for screening of antifertility activity in albino mice. EPUB. 2007;76(6):482-5. https://doi.org/10.1016/j.contraception.2007.08.008.

14. Aarthi N, Murugan K. Antimalarial activity and phytochemical screening of ethanolic leaf extract of phyllanthus niruri and Mimosa pudica. IJPRD. 2011;3(3):198-205

15. Suneetha B, Pavan KP, Prasad KVSRG, Vidyadhara S, Sambasiva RKRS. Hepatoprotective and antioxidant activities of methanolic extract of Mimosa pudica roots against carbon tetrachloride induced hepatotoxicity in albino rats. IRJP. $2011 ; 1(1): 46-53$

16. Rajendran R, Hemalatha S, Akasakalai K, MadhuKrishna CH, Sohil BV, Sundaram MR. Hepatoprotective activity of Mimosa pudica leaves against Carbon tetrachloride induced toxicity. J NAT PROD. 2009;2:116-22.

17. Bendgude RD, Maniyar MG, Kondawar MS, Patil SB, Hirave RV. Anthelmintic activity of leaves of Mimosa pudica. IJIPLS. 2012;2(1):120-5.

18. Rajendran R, Krishnakumar E. Hypolipidemic activity of chloroform extract of Mimosa pudica leaves. AJMB. 2010;2(4):215-1. PMid:23408779 PMCid: PMC3558166.

19. SangmaTK, Meitei UD, Sanjenbam R, Khumbongmayum S. Diuretic property of aqueous extract of leaves of Mimosa pudica Linn. on experimental albino rats. J Nat Prod. 2010;3:172-8.

20. Sutar NG, Sutar UN, Behera BC. Antidiabetic activity of Mimosa pudica Linn in albino rats. J Herb Med. 2009;3(1):123-6.

21. Konsue A, Picheansoonthon C, Talubmook C. $\alpha$-Glucosidase inhibitory activity of extracts from Mimosa pudica L. J Sci Technol MSU. 2015;80-4.

22. AmalrajT, Ignacimuthu, S. Hyperglycemic effect of leaves of Mimosa pudica Linn. Fitoterapia. 2002;73(4):351-2. https://doi.org/10.1016/S0367-326X(02)00079-5.

23. Pushparaj PN, Low HK, Manikandan J, Tan BKH, Tan CH. Antidiabetic effects of Cichorium intybus in streptozotocin induced diabetic rats. J Ethnopharmacol. 2007;111(2):430-4. https://doi.org/10.1016/j.jep.2006.11.028; PMid:17197141.

24. Talubmook C. Effect of polysaccharide from Phellinus ignarius (L) Quel. On hematological values and blood cell characteristic in diabetic rats. JMST. 2008;22:42-5

25. Fang XK, Gao J, Zhu DN. Kaempferol and quercetin isolated from Euony musalatus improve glucose uptake of $3 \mathrm{~T} 3 \mathrm{~L} 1$ cells without adipogenesis activity. Life Sci J. 2008;82(11):615-22. https://doi.org/10.1016/j.Ifs.2007.12.021; PMid:18262572.

26. Junod A, Lambert AE, Stauffacher W, Renold AE. Diabetogenic action of streptozotocin: relationship of dose to metabolic response. JCI. 1969;48(11):2129-39. https://doi.org/10.1172/JCl106180; PMid:4241908 PMCid:PMC297467

27. Padeea P, Nualkaewa S, Talubmookb C, Sakuljaitrongc S. Hypoglycemic effect of a leaf extract of Pseuderanthemum palatiferum (Nees) Radlk. in normal and 
streptozotocin induced diabetic rats. J Ethnopharmacol. 2010;132(2):491-6. https://doi.org/10.1016/j.jep.2010.07.056; PMid:20813181.

28. Kumar PM, SasmalD, Mazumder PM. The antihyperglycemic effect of aerial parts of Salvia splendens (scarlet sage) in streptozotocin-induced diabeticrats. Phcog Res. 2010;2(3):190-4. https://doi.org/10.4103/0974-8490.65520; PMid:21808565PMCid:PMC3141313.

29. Heistad DD. Oxidative stress and vascular disease. ATVB. 2006;26(4): 689-95

30. Maritim AC, Sanders RA, Watkins JB. Diabetes, oxidative stress, and antioxidants: a review. J Biochem Mol Toxicol. 2003;17(1):24-38. https://doi. org/10.1002/jbt.10058; PMid:12616644.
31. Nualkaew S, Padee P, Talubmook C. Hypoglycemic activity in diabetic rats of stigmasterol and sitosterol-3-O- $\beta$-D-glucopyranoside isolated from Pseuderanthemum palatiferum (Nees) Radlk. leaf extract. J Med Plants Res. 2015;9(20):629-35. https://doi.org/10.5897/JMPR2014.5722.

32. Ranjan RK, Kumar MS, Seethalakshmi I, Rao MRK. Phytochemical analysis of leaves and roots of Mimosa pudica collected from Kalingavaram, Tamil Nadu. JCHPS. 2013;5(5):53-5.

33. Seetharam YN, Chalageri G, Setty SR. Bheemachar. Hypoglycemic activity of Abutilon indicum leaf extracts in rats. Fitoterapia. 2002;73(2):156-9. https://doi. org/10.1016/S0367-326X(02)00015-1.

\section{GRAPHICAL ABSTRACT}

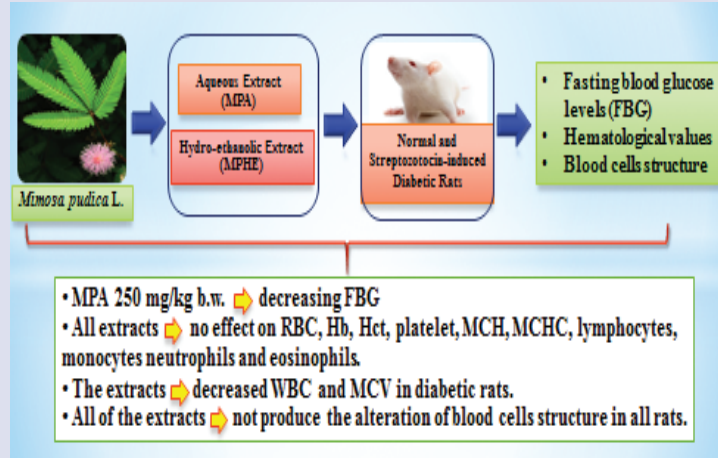

\section{SUMMARY}

- $\quad$ The MPA $250 \mathrm{mg} / \mathrm{kg}$ b.w. showed significantly $(p<0.05)$ decreasing fasting blood glucose levels more potent than glibenclamide.

- All extracts had no effect on $\mathrm{RBC}, \mathrm{Hb}$, Hct, platelet, $\mathrm{MCH}, \mathrm{MCHC}$, lymphocytes, monocytes neutrophils and eosinophils.

- $\quad$ The extracts were decreased WBC and MCV in diabetic rats.

- All of the extracts did not produce the alteration of blood cells structure in all rats.

- $\quad$ The aqueous extract from Mimosa pudica has a beneficial effect in hypoglycemic rats and may prevent the complication of diabetes.

\section{ABOUT AUTHOR}

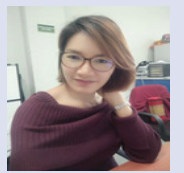

Ampa Konsue: Is a Ph.D. candidate at the Faculty of Medicine, Mahasarakham University, Thailand, where she graduated in Bachelor of Sciences (Applied Thai Traditional Medicine) and Master of sciences (Pharmaceutical chemistry and natural products). Her doctoral research focused on the evaluation of Hypoglycemic effect and mechanisms of action and antioxidant activity of natural products.

Cite this article: Konsue A, Picheansoonthon C, Talubmook C. Fasting Blood Glucose Levels and Hematological Values in Normal and Streptozotocin-Induced Diabetic Rats of Mimosa pudica L. Extracts. Pharmacogn J. 2017;9(3):315-22. 